MA NEMANJA MITROVIĆ, istraživač-stipendista

Institut za savremenu istoriju

Beograd, Republika Srbija

nmitrovic3@gmail.com

originalan naučni rad

UDK: 327(497.1:498)"1968"

327(498)"1968"

primljeno: 10. decembar 2018.

327(497.1)"1968"

prihvaćeno: 9. oktobar 2019.

https://doi.org/10.29362/ist20veka.2020.1.sla.129-146

\title{
MEĐUNARODNI PROBLEMI POSMATRANI KROZ RAZGOVORE NIKOLAE ČAUŠESKUA I JOSIPA BROZA TITA 1968. GODINE
}

APSTRAKT: Tema rada su ključna globalna pitanja koja su imala različit uticaj na jugoslovensko-rumunske odnose i njihovu spoljnu politiku prema velikim silama i drugim zemljama. Istraživanje je vršeno na osnovu poseta rumunskih delegacija na najvišem državnom i partijskom nivou, pri čemu su razgovori između Nikolae Čaušeskua i Josipa Broza Tita ključni za razumevanje ove teme. Reč je o tri takva značajna susreta: poseta Belju januara 1968, zatim zvanična šestodnevna poseta Jugoslaviji od 27. maja do 1. juna i jednodnevni susret dvojice predsednika u Vršcu 24. avgusta 1968. godine. Cilj rada je rekonstrukcija bilateralnih odnosa dve države kroz prizmu krize na Bliskom istoku, savetovanja komunističkih partija, odnosa prema evropskim pitanjima, intervencije pet članica Varšavskog pakta u Čehoslovačkoj i drugih aktuelnih međunarodnih problema.

KLJUČNE REČI: Jugoslavija, Rumunija, Josip Broz Tito, Nikolae Čaušesku, ,praško proleće“, 1968. godina, Hladni rat

Odnosi Jugoslavije i Rumunije su kroz istoriju mahom bili veoma dobri. Tako su i bilateralne odnose Jugoslavije i Rumunije 1960-ih godina karakterisali poverenje, saradnja u svim oblastima, intenzivni kontakti i česta razmena mišljenja najviših i drugih rukovodilaca dve zemlje i partije. Među tim kontaktima se, po svom značaju, posebno izdvajaju susreti dvojice lidera, Nikolae Čaušeskua i Josipa Broza Tita. Oni su se zbog međunarodnih okolnosti i potrebe usaglašavanja političkih stavova i ciljeva sastali čak tri puta u 1968. godini. Tako je „vruća šezdeset osma“ ostala upamćena i po tome što su tada odnosi dve države prevazišli granice bilateralnog konteksta.

Prvi susret u 1968. godini bila je nezvanična poseta realizovana u periodu od 3. do 5. januara na gazdinstvu „Tikveš“ na Belju. ${ }^{1}$ Drugi susret je bila

\footnotetext{
${ }^{1}$ Lov na gazdinstvu „Tikveš” na Belju je bio u stvari druga poseta Nikolae Čaušeskua Jugoslaviji; prvi put je bio u svojstvu šefa rumunske delegacije na Osmom kongresu SKJ decembra 1964, a
} 
zvanična poseta rumunske delegacije od 27. maja do 1. juna 1968. godine. ${ }^{2}$ Ova poseta ostala je upamćena kao prva zvanična poseta rumunskog lidera jednoj stranoj zemlji u funkciji šefa države i partije. ${ }^{3}$ Čaušesku je tada posetio Jugoslaviju po treći put, a četvrti put se sastao sa Josipom Brozom. Značaj posete je bio i u potvrdi dobrih odnosa i u manifestaciji snažnijeg interesa dve zemlje za dalji pozitivan razvoj saradnje. Do poslednjeg susreta u 1968. godini došlo je u Vršcu 24. avgusta. ${ }^{4}$ Iako najkraći, ovaj susret je bio najznačajniji zbog drastičnih promena nastalih na međunarodnoj sceni.

Pre samog razmatranja uticaja glavnih međunarodnih pitanja na odnose Jugoslavije i Rumunije treba nešto reći o položaju Rumunije pred 1968. godinu. Kako stoji u jednom izveštaju: „Unazad nekoliko godina Rumunija je bila veoma aktivna na međunarodnom planu. Intenzivirala je odnose sa zemljama Zapada, uspostavila odnose sa SR Nemačkom, bila je aktivna oko neproliferacije ${ }^{5}$ u Ženevi, a realizovane su i važne posete poput Maurerove ${ }^{6}$ Vašingtonu i Parizu i posete Moskvi gde su bili vođeni razgovori sa sovjetskim rukovodstvom“.7 Dakle, za relativno kratko vreme Rumunija je uspela da se afirmiše kao samostalan faktor u međunarodnim odnosima i pokaže da se njenom politikom ne upravlja iz Moskve već iz Bukurešta.

ova poseta je bila prva kao generalnog sekretara Rumunske komunističke partije i predsednika Državnog saveta (funkciju generalnog sekretara vršio je od 1965. godine, a predsednik Državnog saveta postao je decembra 1967. posle ostavke Kivu Stojka).

${ }^{2}$ Do zvanične posete Nikolae Čaušeskua Jugoslaviji trebalo je da dođe jula 1967, ali je ona odložena samo nekoliko dana pre određenog termina. Glavni razlog otkazivanja bila je kriza na Bliskom istoku nastala izbijanjem Šestodnevnog rata (5-10. jun 1967), ratnog sukoba između Izraela s jedne i Egipta, Jordana i Sirije s druge strane. Program posete iz 1968. godine bio je zasnovan na dorađenom materijalu pripremljenom za nerealizovanu posetu iz juna 1967.

${ }^{3}$ Arhiv Jugoslavije (AJ), Kabinet Predsednika Republike (KPR), I-3-a/97-21, dok. 264/1, Zabeleška o razgovoru SDS S. Babića sa ambasadorom SR Rumunije Aurelom Malnašanom.

${ }^{4}$ AJ, KPR, I-3-a/97-22, Informacije o razgovorima Tito-Čaušesku, 24. avgust 1968.

${ }^{5}$ Neproliferacija - neširenje nuklearnog oružja. Prvi napori usmereni ka neširenju nuklearnog materijala datiraju neposredno nakon Drugog svetskog rata kada je Trumanova administracija predložila Baruhov plan (14. juna 1946) u kojem je predložen međunarodni nadzor nad upotrebom nuklearne energije s namerom da se izbegne nesmetano širenje nuklearne tehnologije. Rad na sprečavanju širenja nuklearnog oružja počeo je tek nakon što je NR Kina 1964. testirala svoju atomsku bombu. Godine 1968. predložen je tekst Ugovora o neproliferaciji, koji je 1. jula iste godine usvojen u Ujedinjenim nacijama, a na snagu stupio 1970. godine (Nuklearna energija mistika i stvarnost, http://www.nemis.hr, pristupljeno 21. 5. 2018). Jugoslavija se naročito angažovala oko pomenutog ugovora. Ubrzo po postizanju sporazuma jugoslovenski predstavnici su ga potpisali 10. jula. Od 1968. pa do trenutka kada je ugovor zaživeo 1970. godine, Jugoslavija se aktivno zalagala za razoružavanje i istakla se kao jedan od predvodnika nenuklearnih zemalja. Dragomir Bondžić, Između ambicija i iluzija. Nuklearna politika Jugoslavije 1945 -1990 (Beograd, Institut za savremenu istoriju, 2016), 193.

${ }^{6}$ Jon George Maurer (1902-2000). Po obrazovanju je bio pravnik, izvesno vreme se bavio i advokatskim pozivom. Komunističkoj partiji je pristupio 1936. Za vreme Drugog svetskog rata zbog političke aktivnosti bio je uhapšen i interniran u logor. Po završetku rata, postao je član CK. Bio je blizak nacionalnoj politici G. Deža, zbog čega je 1957. postao ministar inostranih poslova. Funkciju predsednika Ministarskog saveta vršio je od 1961. do 1974. kada ga je smenio Čaušesku, kome je inače pomogao da dođe na vlast 1965. Umro je u Bukureštu. Ostao je upamćen i kao jedan od najdugovečnijih rumunskih političara.

${ }^{7}$ AJ, KPR, I-3-a/97-20, Podsetnik za razgovore sa Čaušeskuom i njegovim saradnicima. 


\section{Jugoslavija i Rumunija u vrtlogu Hladnog rata}

Pečat rumunskoj spoljnoj politici, naročito od dolaska Nikolae Čaušeskua na vlast, davala je aktivnost ka učvršćivanju i afirmaciji nezavisne pozicije u međunarodnim odnosima. ${ }^{8}$ Ona je želela da izađe iz uskih lagerskih okvira i da dobije širi svetski značaj. ${ }^{9}$ U cilju osiguravanja prostora za afirmaciju ekonomske i političke nezavisnosti Rumunija je težila da uspostavi dobre odnose sa Kinom i SAD. ${ }^{10} \mathrm{U}$ ovakvim rumunskim nastojanjima Jugoslavija je imala posebno mesto i značaj. Ona je kao nezavisna socijalistička država trebalo da pomogne Rumuniji da se lakše odupre pritiscima, da afirmiše njenu međunarodnu politiku i predstavi je zemljama Trećeg sveta. ${ }^{11}$ Jugoslavija je za Rumuniju bila kopča sa Zapadom, važan oslonac u njenim spoljnopolitičkim nastojanjima i često slušan savetnik. Politička stremljenja Bukurešta su bila interesantna i Zapadu. Smatrali su da bi pomaganje jedne zemlje Istočnog bloka koja je težila samostalnosti slabilo pozicije SSSR-a i rušilo monolitnost bloka. Rumunska želja za brzim razvitkom ekonomije i modernizacijom industrije, međutim, pružala bi priliku za zaključivanje krupnih trgovinskih ugovora. ${ }^{12}$

S druge strane, Jugoslavija je bila u ,sivoj zoni“ te je mogla da lavira između Istoka i Zapada. To je ujedno bio i ključ za uspeh jugoslovenske spoljne politike. Jedan od drastičnijih zaokreta u jugoslovenskoj politici desio se izbijanjem arapsko-izraelskog rata juna 1967. Tada je Tito zbog bezrezervne podrške arapskoj strani, a nemoći da konkretnije pomogne Gamalu Abdelu Naseru stao uz SSSR koji je jedini mogao da pruži ozbiljniju pomoć. Približavanje Sovjetskom Savezu je, naravno, bilo inspirisano i ličnim razlozima. Najvažniji su bili strah od američkog prodora u Mediteranu, ali i na Balkanu i nastojanje da se ovom krizom dokaže ispravnost ubeđenja o neophodnosti formiranja pokreta nesvrstanih. Vezivanje Jugoslavije za lager se najočiglednije pokazalo prilikom Titovog učešća na savetovanjima u Moskvi 9. juna, Budimpešti 11. jula, Beogradu i Varšavi 1967. godine, gde je usvojena zajednička strategija borbe protiv imperijalizma. ${ }^{13}$

U prvoj polovini 1968. godine glavne teme koje su zanimale jugoslovenski i rumunski vrh bile su bliskoistočna kriza, savetovanja komunističkih partija i evropska bezbednost. Osim navedenih treba pomenuti i rat u Vijetnamu, ${ }^{14}$ sovjet-

\footnotetext{
${ }^{8}$ Ashby B. Crowder, Legacies of 1968: Autonomy and Represion in Ceausescu's Romania, 19651989 (Ohaio, 2007), 17.

${ }^{9}$ To ne znači da je želela da zaoštri ili raskine odnose sa SSSR-om, već da sa njim i drugim socijalističkim zemljama uspostavi saradnju na novim osnovama, čiji bi principi bili ravnopravnost $\mathrm{i}$ nezavisnost.

${ }^{10}$ Elena Dragomir, "The perceived threat of hegemonismin Romania during the second de' tente", Cold War History, vol. 12, no. 1, (February 2012), 111-134.

${ }^{11}$ AJ, KPR, I-3-a/97-20, Informacije o poseti Čaušeskua u Belju.

${ }^{12}$ Isto.

${ }^{13}$ Dragan Bogetić, Jugoslovensko-američki odnosi 1961-1971 (Beograd: Institut za savremenu istoriju, 2012), 212-217.

14 Jugoslavija i Rumunija su osuđivale agresiju SAD u Vijetnamu i izražavale solidarnost sa borbom vijetnamskog naroda za slobodu i nezavisnost. Povoljno su ocenile početak pregovora
} 
sko-kineski sukob, politiku nesvrstanosti, regionalne probleme i druge o kojima ovde neće biti reči.

Situacija na Bliskom istoku i sukob Izraela sa arapskim zemljama doveli su do izvesnog hlađenja odnosa između Beograda i Bukurešta u drugoj polovini 1967. godine. Postojale su razlike u pogledu ocene koja je strana kriva za izbijanje sukoba ${ }^{15} \mathrm{Na}$ Moskovskom savetovanju komunističke partije su se saglasile sa Titovim programom hitne pomoći arapskim zemljama. ${ }^{16}$ Zajednički kominike su potpisale sve partije osim rumunske. Čaušesku je smatrao da američkim imperijalistima odgovara što duže zadržavanje zategnute situacije na Bliskom istoku, što je po njemu jačalo snagu reakcionarnih krugova u arapskim zemljama, a sa njima su jačale i američke pozicije na tom prostoru. Rumuni su isticali da podržavaju primenu rezolucije Saveta bezbednosti u traženju političkog rešenja i zalagali su se za direktne pregovore koji bi mogli doneti zadovoljavajuće rešenje za obe strane. ${ }^{17} \mathrm{Na}$ kraju, u arapsko-izraelski spor su se umešale velike sile i na predlog Velike Britanije 22. novembra 1967. doneta je Rezolucija UN 242, koja je zahtevala hitno izraelsko povlačenje sa okupiranih teritorija i priznavanje nezavisnosti Izraela. Ovakvo rešenje nije bilo zadovoljavajuće ni za jednu stranu, zbog čega je sukob nastavljen. ${ }^{18}$ Već na samom početku 1968. godine Rumunija je pokazala želju da bliskoistočna kriza više ne predstavlja spornu tačku u diplomatskim odnosima sa Jugoslavijom. Bukurešt je razlike u stavovima koje su po ovom pitanju i dalje postojale zaobilazio, vezujući ih za prošlost. Čaušeskua je naročito zabri-

između predstavnika DR Vijetnama i SAD i tražile hitnu obustavu bombardovanja što bi, po njihovom mišljenju, pomoglo pronalaženju političkog problema vijetnamske krize na bazi Ženevskog sporazuma iz 1954. godine. AJ, КПР, I-3-a/97-21, Zajedničko saopštenje.

15 Čaušesku je smatrao da su Arapi krivi za izbijanje rata, jer su izjavama poput „uništićemo Izrael“" isprovocirali Izrael da napadne Egipat i Siriju. Tito je, s druge strane, za glavnog krivca Šestodnevnog rata označio SAD. On je uz velike napore uspeo da ubedi arapsku stranu u neophodnost pronalaženja kompromisnog rešenja i da zaustavi radikalne arapske zahteve za osvetom, odigravši veliku ulogu u smirivanju situacije i zaustavljanju novog rata. AJ, KPR, I-3a/97-20, dok. 1226/8, Stenogramske beleške sa razgovora vođenih na Belju između Predsednika SFRJ i Predsednika SKJ Josipa Broza Tita i generalnog sekretara KP Rumunije i predsednika Državnog saveta Socijalističke Republike Rumunije Nikolae Čaušeskua dana 3. januara 1968. u 10 časova.

${ }^{16}$ Predsednik Jugoslavije je imao plan za rešavanje bliskoistočne krize, koji je podrazumevao da se Izrael povuče sa zaposednutih teritorija, s tim što bi se garantovale granice. To bi de facto bilo priznavanje Izraela od strane arapskih država. Tito je u razgovoru sa Naserom 11. avgusta govorio o neophodnosti okretanja realnoj politici i pronalaženju kompromisnog rešenja, otvoreno je izneo Naseru činjenicu da je Izrael država koju priznaje većina u Organizaciji ujedinjenih nacija i da se to neće promeniti. Kriza na Bliskom istoku je uticala na poboljšanje jugoslovensko-sovjetskih odnosa. Sovjetski Savez je morao pažljivo odmeravati svoje poteze na Bliskom istoku zbog slabe pozicije. Moskva je usled toga u Josipu Brozu Titu videla pogodnog posrednika, zbog njegovih širokih veza u arapskom svetu. Đoko Tripković, Jugoslavija-SSSR 1956-1971 (Beograd: Institut za savremenu istoriju, 2012), 198-202.

${ }^{17}$ AJ, KPR, I-3-a/97-20, dok. 1226/8, Stenogramske beleške sa razgovora vođenih na Belju između Predsednika SFRJ i Predsednika SKJ Josipa Broza Tita i generalnog sekretara KP Rumunije i predsednika Državnog saveta Socijalističke Republike Rumunije Nikolae Čaušeskua dana 3. januara 1968. u 10 časova.

${ }_{18}$ D. Bogetić, Jugoslovensko-američki odnosi 1961-1971, 243-247. 
njavao nepopustljiv stav Izraela i odbijanje primene Rezolucije Saveta bezbednosti. Smatrao je da je rešenje krize moguće samo političkim putem. Do zbližavanja po ovom pitanju došlo je zahvaljujući sličnom mišljenju - da je za miroljubivo rešenje krize neophodno povlačenje izraelskih trupa sa svih okupiranih arapskih teritorija i priznavanje prava na opstanak, suverenitet i teritorijalni integritet svih država na tom području. ${ }^{19}$

\section{Odnos Jugoslavije i Rumunije prema politici Istočnog bloka}

Značajno za obe države bilo je i pitanje organizovanja savetovanja komunističkih partija. Rumunija je, u principu, bila za održavanje ovakvih međunarodnih skupova. Problem su, međutim, predstavljale međunarodne okolnosti. Po mišljenju rumunskih zvaničnika u tom trenutku nisu postojali uslovi za održavanje predviđenog međunarodnog savetovanja KP. Pre svega zbog američkog imperijalizma Vijetnam, Koreja i Kuba ne bi učestvovale, a ni Kina i Albanija zbog sukoba sa SSSR-om. Oni su bili izričito protiv donošenja bilo kakvih dokumenata koji bi obavezivali na poštovanje generalne linije, a i protiv toga da se na savetovanju diskutuje o politici pojedinih partija. ${ }^{20}$

I pored iznetih stavova, Rumunija je ipak odlučila da prisustvuje pripremnom sastanku u Budimpešti februara 1968. godine. Razlozi za to bili su da nije želela da svojim odsustvom pruži priliku da drugi neobjektivno interpretiraju njene stavove i da odsustvom jača one snage koje su težile ,vraćanju na staro“. Na svoje učešće na sastanku u Budimpešti Komunistička partija Rumunije je gledala i kao na mogućnost aktivnog uticaja na tok priprema za savetovanje. ${ }^{21}$ U učešću je viđena prilika da Rumunija iznese svoje stavove, smatrali su da bi im to pomoglo da lakše opravdaju neučestvovanje u savetovanju ukoliko ono ne bude onakvo za kakvo su se zalagali u svojim naporima na pripremnom sastanku. ${ }^{22} \mathrm{Zbog}$ činjenice da su se njeni pogledi razlikovali od pogleda većine članica Istočnog bloka, Rumuniji je bila potrebna podrška bar nekoliko drugih država. Rumuni su se zalagali za učešće SKJ na pripremnom savetovanju u Budimpešti, jer je Jugoslavija imala određen ugled na međunarodnoj sceni te bi podrška jedne takve zemlje pomogla da rumunski stavovi ne ostanu skrajnuti. Štaviše, Rumunija je smatrala da je Jugoslavija njen saveznik u naporima usmerenim na organizaciju savetovanja. ${ }^{23}$

${ }^{19}$ AJ, KPR, I-3-a/97-20, dok. 1226/8, Stenogramske beleške sa razgovora vođenih na Belju između Predsednika SFRJ i Predsednika SKJ Josipa Broza Tita i generalnog sekretara KP Rumunije i predsednika Državnog saveta Socijalističke Republike Rumunije Nikolae Čaušeskua dana 3. januara 1968. u 10 časova.

${ }^{20}$ Isto.

${ }^{21}$ Diplomatski arhiv Ministarstva spoljnih poslova Republike Srbije (DA MSP), Politička arhiva (PA), Rumunija, 1968, f. 157, dok. 41984, Šandru i drugi funkcioneri MIP-a o susretu na Belju, 15. 1.1968.

${ }^{22}$ Rumunsko učešće $u$ Budimpešti nije bilo na visokom nivou, te nije obavezivalo Rumuniju da učestvuje na samom savetovanju, a bilo je korisno zbog uticaja na izradu platforme savetovanja ili eventualno njegovog odlaganja.

${ }^{23}$ DA MSP, PA, Rumunija, 1968, f. 157, dok. 4721, Poseta Nikolae Čaušeskua Jugoslaviji kabinet Babića, 11. 1. 1968. 
Jugoslovenski stavovi u vezi sa pripremnim sastankom i savetovanjem komunističkih partija su se razlikovali od rumunskih. Tito je naročito naglašavao činjenicu da jugoslovenska i rumunska pozicija nisu iste. ${ }^{24} \mathrm{Ipak}$, odbijanje učešća nije značilo prekid odnosa sa Istokom. U nekoliko navrata Tito je tokom 1968. godine isticao da će „SKJ i dalje razvijati odnose saradnje sa svim komunističkim partijama, upoznavati ih sa svojim stavovima i težiti proširenju saradnje“. ${ }^{25}$ Razlog više za neučestvovanje jugoslovenske delegacije je viđen na pomenutom sastanku u Budimpešti gde se čvrsto stajalo na deklaracijama komunističkih partija iz 1957. i 1960. godine u kojima je Jugoslavija osuđivana i kritikovana. ${ }^{26} \mathrm{Na}$ kraju ni Rumunija nije bila zadovoljna tokom pripremnog sastanka, te je njena delegacija napustila Budimpeštu pre završetka savetovanja. ${ }^{27}$

Napuštanjem savetovanja u Budimpešti, izdvajanjem iz deklaracije o nuklearnoj neproliferaciji u Sofiji ${ }^{28}$ i neučešćem na sastanku Saveta za uzajamnu ekonomsku pomoć (SEV) u Drezdenu, ${ }^{29}$ Rumunija je stvorila novu situaciju

${ }^{24}$ Jugoslavija nije primila poziv, inicijatori su se pozivali na kontinuitet ranijih savetovanja, isticali jugoslovenski položaj nesvrstane zemlje, pitanje spremnosti da se o stavovima SKJ vode konstruktivni i tolerantni razgovori.

${ }^{25}$ AJ, KPR, I-3-a/97-20, dok. 1226/8, Stenogramske beleške sa razgovora vođenih na Belju između Predsednika SFRJ i Predsednika SKJ Josipa Broza Tita i generalnog sekretara KP Rumunije i predsednika Državnog saveta Socijalističke Republike Rumunije Nikolae Čaušeskua dana 4. januara 1968.

${ }^{26}$ AJ, KPR, I-3-a/97-21, Zabeleške o razgovorima.

${ }^{27}$ Najvažnija tačka konsultativnog sastanka 64 komunističke partije, koji je održan februara i marta 1968. u Budimpešti, bila je vezana za sazivanje međunarodne komunističke konferencije. Stav rumunskog delegata Nikulesku Mizila je bio da na konferenciji treba „stvoriti uslove koji bi okupili sve partije bez izuzetka, i po mogućstvu privukli i druge napredne snage". Među ostalim partijama postojale su dve struje, prva se zalagala za pozivanje svih partija koje su sebe smatrale komunističkim, a druga da se broj učesnika na konferenciji ograniči, makar na potpisnike Moskovske deklaracije iz 1960. godine. Napad šefa delegacije KP Sirije Kaleda Bagdaša na rumunsku delegaciju i politiku rumunske partije uticao je na odluku Rumunije da napusti konferenciju. Ona je to učinila posle procene da konferencija u Budimpešti nije mogla da se distancira od sirijskih napada i pruži garancije da se tako nešto neće ponoviti u odnosu prema partijama koje su prisustvovale konferenciji, ali i u odnosu na druge partije. „Završen konsultativni sastanak KP u Budimpešti“, Politika, 6. 3. 1968.

${ }^{28}$ U Budimpešti je odlučeno da se u Sofiji 6. marta 1968. održi sastanak političko-konsultativnog komiteta Varšavskog pakta. Predlog o sastanku članica ovog pakta u Sofiji iznela je Rumunija sa ciljem da se zajednički analizira i oceni nacrt ugovora o neproliferaciji pre njegovog potpisivanja i kako bi se izneli predlozi za njegovo poboljšavanje. Tražila je jednake garancije bezbednosti kako za velike tako i za male države, zatim da ugovor predstavlja sastavni deo procesa razoružavanja i da pruži mogućnost korišćenja nuklearne energije u miroljubive svrhe. Ostale članice su podržale stav SSSR-a i potpisale zajednički dokument, Deklaraciju šest zemalja o neproliferaciji. Pošto nije došlo do ozbiljnog razmatranja rumunskih zahteva, Rumunija je odlučila da se njen potpis ne nađe na dokumentu. AJ, KPR, I-3-a/97-21, Zapisnik razgovora Vladimira Bakarića, člana Predsedništva SKJ i Predsednika SKH sa Emil Bodnarošom, članom Stalnog Prezidijuma, 7. maj 1968. godine; ,Rumunija traži iste garancije za velike i male države", Politika, 14. 3.1968.

${ }^{29}$ Rumunija nije bila pozvana na sastanak komunističkih partija-članica Saveta za uzajamnu ekonomsku pomoć i Varšavskog ugovora 23. marta u Drezdenu. Razlog je bio stav da bi ona usporila i samo ometala rad i prihvatanje već unapred donetih odluka. Rumunija je potrebu za 
u odnosima prema Varšavskom paktu i njegovim članicama. Slična situacija je bila u odnosu sa SEV-om, jer je Bukurešt bio nezadovoljan predlogom o novim merama za organizaciju i rad SEV-a i pozivom za sastanak prvih sekretara KP zemalja SEV-a za 25. jun. Taj predlog je ocenjen kao težnja nekih članica da se njeni organi pretvore u neko naddržavno telo koje bi imalo sva ovlašćenja za izdavanje naređenja svim nacionalnim privredama. Ni ostali predlozi nisu bili prihvatljivi za Rumuniju. Na primer, predlog da se rublja pretvori u konvertibilnu valutu za sve članice SEV-a, ili da se kurs nacionalnih moneta ostalih zemalja članica utvrđuje od strane banke koju bi osnovao SEV. Tu je bio i predlog o koordinaciji spoljne trgovine po kome niko ne bi mogao da izvozi samostalno, već bi sve išlo preko jednog koordinacionog biroa. ${ }^{30}$

Za Rumuniju je bilo važno i pitanje nuklearne neproliferacije. Čaušesku je često ukazivao na negativne postupke i pritiske SSSR-a i nekih drugih socijalističkih zemalja u nastojanju da se prihvati nacrt ugovora o neproliferaciji bez davanja mesta daljim nastojanjima za njegovo poboljšanje. Kao element pritiska rukovodstvo je videlo zaobilaženje Rumunije u Drezdenu. U međuvremenu došlo je do izvesnih poboljšanja u ugovoru o neproliferaciji u čemu je Rumunija, pozitivno ocenivši te promene, videla potvrdu ispravnosti svojih nastojanja. Zadovoljna izmenama, Rumunija je i potpisala ugovor. ${ }^{31}$ Još krajem četrdesetih godina Jugoslavija i Rumunija su počele sa razvojem na polju korišćenja nuklearne energije u miroljubive svrhe. ${ }^{32}$ Dve države su septembra 1967. potpisale Sporazum o naučno-tehničkoj saradnji u oblasti korišćenja nuklearne energije u miroljubive svrhe. Široko zamišljena, ova saradnja nije ostvarila postavljene ciljeve najviše zato što je jugoslovensko rukovodstvo od početka 60 -ih godina počelo da zapostavlja i smanjuje ulaganja u nuklearna istraživanja. ${ }^{33}$

Evropska bezbednost je bilo pitanje koje se direktno ticalo i Jugoslavije i Rumunije. Polazeći od pozitivnih promena u Evropi (popuštanje zategnutosti, proširenje saradnje itd.), Bukurešt je pokazivao veliku zainteresovanost za proširenje veza sa zemljama Zapadne Evrope. Naročito veliku podršku rumunskog rukovodstva imala je politika Vilija Branta. Podrška Brantovim nastojanjima indirektno je pokazivala neslaganje Rumunije sa stavovima iznetim u noti

sastankom videla u zabrinutosti SSSR-a zbog razvoja situacije u Čehoslovačkoj. Sastanak je trebalo da posluži kao sredstvo pritiska na rukovodstvo ČSSR-a da zaustavi proces demokratizacije. Umesto pritiska i kočenja sastanak je samo ubrzao procese u Čehoslovačkoj. U Drezdenu se raspravljalo i o problemima obe organizacije čiji je Rumunija bila član od osnivanja. AJ, KPR, I-3-a/97-21, Zabeleške o razgovoru Vladimira Bakarića sa Bandorošem; „Plenum CK Rumunske komunističke partije“, Politika, 27. 4. 1968.

${ }^{30} \mathrm{AJ}, \mathrm{KPR}, \mathrm{I}-3-\mathrm{a} / 97-21$, Zabeleške o razgovorima.

${ }^{31}$ Isto.

${ }^{32}$ Sonja Schmid, "Nuclear Colonization?: Soviet Technopolitics in the Second World", u: Entangled Geographies: Empire and Techologies in the Global Cold War, Editor Gabrielle Hecht (Cambridge, MIT Press, 2011, 130).

${ }^{33}$ D. Bondžić, $n$. d., 202; AJ, fond 177, Savezna komisija za nuklearnu energiju (SKNE), 177-2-2, Sporazum između SFRJ i SR Rumunije o naučno-tehničkoj saradnji u oblasti korišćenja nuklearne energije u miroljubive svrhe, 16. septembar 1967. 
SSSR-a u Bonu. Rumuni su dalje pozdravljali normalizaciju odnosa SR Nemačke i Jugoslavije, videvši u tome put da Nemačka Demokratska Republika (NDR) učvrsti svoj međunarodni položaj. Priznavanje Istočne Nemačke od strane Jugoslavije prekinulo je odnose sa Zapadom Nemačkom, koji su ostali takvi sve do dolaska Branta, a sa njim i fleksibilnije politike. Posle toga je Jugoslavija imala veoma razvijene ekonomske veze sa Zapadnom Nemačkom, a tamo se nalazio i veliki broj jugoslovenskih radnika, čiji status tada još nije bio rešen međudržavnim ugovorom. ${ }^{34}$

Jugoslovenski i rumunski partijski funkcioneri su se slagali oko toga da je za unapređivanje saradnje i bezbednosti u Evropi neophodno ravnopravno učešće svih evropskih zemalja, uključujući i dve nemačke države u rešavanju evropskih problema. Dve strane su smatrale da je u interesu nastavka demokratizacije međunarodnih odnosa u Evropi neophodno eliminisanje ekonomskih i političkih barijera. Ovde je kao posebno značajna isticana rezolucija o unapređivanju dobrosusedskih odnosa među evropskim državama sa različitim društvenim i političkim sistemima, koja je usvojena na 20. zasedanju Generalne skupštine OUN. ${ }^{35}$

Tito i Čaušesku su redovno razmenjivali stavove o blokovskoj podeli. Tokom 1968. ova tema se naročito isticala zbog približavanja 1969, to jest 20 godina od nastanka NATO pakta. U razgovorima se postavljalo pitanje produžavanja ugovora i njegove korisnosti. Sagovornici su smatrali da je mala verovatnoća da će doći do likvidacije pakta, ali da je moguće postići ublažavanje nekih odredaba tog sporazuma, pod uslovom poboljšanja odnosa socijalističkih zemalja sa članicama NATO pakta. ${ }^{36}$ Smatrali su da je postojanje ove organizacije bilo direktno vezano za postojanje Varšavskog pakta. Ova dva vojnopolitička bloka, iako suprotstavljena, bila su po mišljenju rumunskog i jugoslovenskog lidera međusobno zavisna.

Rumunija je tokom svih razgovora jasno iznosila želju za boljim povezivanjem sa Zapadom, a zbližavanje sa Jugoslavijom je tome trebalo da doprinese. Razgovori sa Josipom Brozom su uticali na Nikolae Čaušeskua da odlučnije zastupa rumunske stavove i čvršće vodi nezavisnu politiku. Toga će se pridržavati sve do istorijskog avgusta 1968. Posle toga, u uslovima promenjene međunarodne situacije zbog intervencije pet zemalja Varšavskog pakta u Čehoslovačkoj, mogao se primetiti napor Rumunije da se elastičnije postavi u odnosima sa Sovjetskim Savezom. ${ }^{37}$

\footnotetext{
${ }^{34}$ DA MSP, PA, Rumunija, 1968, f. 157, dok 4721, Poseta Nikolae Čaušeskua Jugoslaviji kabinet Babića, 11. 1. 1968.

${ }^{35}$ AJ, KPR, I-3-a/97-21, Zajedničko saopštenje.

${ }^{36}$ Isto.

${ }^{37}$ DA MSP, PA, Rumunija, 1968, f. 157, dok. 4721, Poseta Nikolae Čaušeskua Jugoslaviji kabinet Babića, 11. 1. 1968.
} 


\section{Uticaj „praškog proleća“ na Jugoslaviju i Rumuniju}

Glavna tema koja je okupirala pažnju jugoslovenskih, rumunskih, ali i drugih političara tokom čitave 1968 . godine bilo je čehoslovačko pitanje. ${ }^{38}$ Godina 1968. predstavljala je za Istočni blok trenutak povlačenja iz revizionizma i bujanja različitih disidentskih pokreta. Štaviše, mnogi istoričari ovu godinu uzimaju kao početak raspada komunističkog režima, a kao preloman događaj uzima se intervencija u Čehoslovačkoj. Da ponovimo često citiranu rečenicu Tonija Džada koja praško proleće smešta na pravo mesto u istoriji: „Uprkos činjenici da je Berlinski zid pao 1989. godine, duša komunizma je umrla dvadeset godina ranije u Pragu avgusta 1968. godine“..$^{39}$

Rumunski vrh je pokazivao značajno interesovanje za događaje u Čehoslovačkoj Socijalističkoj Republici još od prvih januarskih dana ,praškog proleća“. Rumuni su se nadali da će stvaranje još jedne nezavisne spoljne politike u

38 Čehoslovačko pitanje je otvoreno na Trećem plenumu CK KPČ održanom od oktobra 1967. do januara 1968. Na plenumu je smenjen Antonjin Novotni, a Aleksandar Dubček je postao sekretar CK KPČ. Ovom promenom omogućeno je otvaranje pitanja daljeg razvoja socijalizma. Na sastanku partijskih i vojnih rukovodstava SSSR-a, Bugarske i Istočne Nemačke u Drezdenu 23. marta 1968. izneti su stavovi da se Čehoslovačka polako uvlači u revizionizam, da u njoj jačaju buržoaska ideologija i špijunaža, da se iza parola o demokratizaciji i liberalizaciji kriju antisocijalistički elementi i da sve to vodi sukobu. Donete su odluke kako bi se zaustavio proces demokratizacije u Čehoslovačkoj. Sukob je postao neminovan donošenjem Akcionog programa KPČ 30. aprila. Nove ideje koje su tu iznete suprotstavljale su se svemu postojećem u ČSSR, ali i važećem u Istočnom bloku. Akcioni plan je zagovarao saradnju sa SSSR-om, ali na principima uzajamnog poštovanja, suverenosti i ravnopravnosti i poštovanja specifičnih nacionalnih interesa. Novo rukovodstvo KPČ u svojim reformama nije videlo ništa štetno po sistem, za njih „socijalizam nije bio sporan, sporan je bio mehanizam naređivanja“. Ljubodrag Dimić, Jugoslavija i Hladni rat (Beograd: Arhipelag, 2014), 321-327. Cilj Dubčekovog „socijalizma sa ljudskim likom" bio je da spoji socijalnu sigurnost sa ljudskim pravima, a ne da zameni socijalizam nekim drugim sistemom. Драган Богетић, „Југословенско-совјетски односи у светлу војне интервенције у Чехословачкој 1968. године“, у: 1968 - четрдесет година после, уредница Радмила Радић (Београд: Институт за савремену историју, 2008), 129-162; Đоko Tripković, „Međunarodni položaj Jugoslavije i vojna intervencija u Čehoslovačkoj“, Istorija 20. veka, god. XXVI, br. 1, (2008), 115-130. Ovakav socijalizam je bio primamljiv mnogim komunističkim zemljama. Slični pokušaji demokratizacije javili su se u Poljskoj, ali je rukovodstvo predvođeno Vladisavom Gomulkom uspelo da suzbije pokret. Ovo je naročito plašilo Moskvu. Ultimativni ton pisma iz Varšave nije uticao na odlučnost rukovodstva da nastavi reforme. Lažnu nadu da je moguće izbeći intervenciju davali su sastanci KPČ-a i KPSS-a - prvi u Černi na Tisi 29. jula, a drugi u Bratislavi 3. avgusta. Волтер Лакер, Историја Европе 1945 1992 (Београд: Clio, 1999), 438-440; Љубодраг Димић, „Година 1968 - исходиште нове југословенске политике“, у: 1968 - четрдесет година после, 339-378; Günter Bischof, Stefan Karner and Peter Ruggenthaler, The Prague Spring and the Warsaw Pact Invasion of Czechoslovakia in 1968 (Plymouth: Lexington Books, 2010); Mihai Retegan, In the Shadow of the Prague Spring: Romanian Foreign Policy and the Crisis in Czechoslovakia 1968 (Buchurest: Center for Romanian Studies, 2000); Kevin McDermott and Matthew Stibbe, Eastern Europe in 1968: Responses to the Prague Spring and Warsaw Pact Invasion (Cham: Palgrave MacMillan, 2018).

${ }^{39}$ Tony Judt, Postwar: A History of Europe since 1945 (New York: Penguin Press, 2005), 447. 
odnosu na Sovjetski Savez uticati na značajno poboljšanje rumunskog položaja. Nikolae Čaušesku je blagonaklono gledao na dešavanja u Čehoslovačkoj. Bio je mišljenja da KP Čehoslovačke treba ostaviti da samostalno rešava sve probleme unutrašnjeg razvoja zemlje, bez ikakvog mešanja sa strane. ${ }^{40}$

Formiranje još jedne, čehoslovačke, nezavisne spoljne politike, pored jugoslovenske, bilo bi za Rumuniju veliko ohrabrenje. Imajući to u vidu nije teško zaključiti da je Josip Broz Tito za Nikolae Čaušeskua i rumunske rukovodioce bio najsigurniji i najkorisniji konsultant. ${ }^{41} \mathrm{~S}$ tim u vezi, od naročitog značaja za Bukurešt bilo je da se bolje upozna sa reakcijom i odnosom Beograda prema promenama u Čehoslovačkoj. ${ }^{42}$

Kriza u Čehoslovačkoj je posebno zbližila dve zemlje. Stavovi Bukurešta i Beograda o ovom pitanju bili su gotovo identični. Tito je, na primer, smatrao da se reforme u Čehoslovačkoj odvijaju pod kontrolom partije i da zbog toga pravac procesa ne predstavlja opasnost po socijalizam u Čehoslovačkoj, već za njegovo dalje razvijanje. Čaušesku je procese u ČSSR-u razumeo kao „učvršćivanje tekovina revolucije“, te je zbog toga mislio da oni ne treba da utiču na odnose sa zemljama lagera. „KP Čehoslovačke treba ostaviti da samostalno rešava sve probleme unutrašnjeg razvoja zemlje, bez ikakvog mešanja sa strane". 43

Tokom razgovora dvojice predsednika na Belju i tokom zvanične posete često je podvlačena saglasnost $i$ bliskost stavova u pogledu principa i korisnosti bilateralne i multilateralne saradnje među komunističkim i radničkim partijama. Naročito se insistiralo na poštovanju principa nezavisnosti i ravnopravnosti, proleterskog internacionalizma, uvažavanja specifičnosti svake zemlje i stvaralačkog razvoja socijalističke teorije i prakse. Smatrali su da u odnosima između partija treba isticati ono što ih povezuje, a to je borba za mir, progres i socijalizam. Na primeru događaja u Čehoslovačkoj isticana je podrška svim naporima u pravcu demokratskog razvoja socijalističkog društva i podvlačeno je ,isključivo pravo svake partije da samostalno utvrđuje politiku u izgradnji socijalizma u svojoj zemlji““. ${ }^{4}$

Sredinom 1968. jugoslovensko-rumunski odnosi su počeli da prevazilaze bilateralne okvire. Razlog tome su, osim slične spoljnopolitičke orijentacije, bili i događaji u Čehoslovačkoj. Osećaj da će se eventualno neželjen rasplet „praškog proleća“ odraziti i na stanje u Jugoslaviji i Rumuniji sve je više plašio dva lidera. U razgovorima tokom zvanične rumunske posete od 27. maja do 1. juna često su isticani principi nacionalne suverenosti i nezavisnosti, ravnopravnosti i nemešanja u unutrašnje stvari drugih zemalja. Bili su ubeđeni da će poš-

\footnotetext{
${ }^{40}$ Lj. Dimić, Jugoslavija i Hladni rat, 344-345.

${ }^{41}$ DA MSP, PA, 1968, f. 155, dok. 415896, Materijal u vezi zvanične posete Čaušeskua Jugoslaviji, 26. 6. 1968.

42 Dešavanjima u Čehoslovačkoj je zbog toga posvećena posebna pažnja tokom zvanične posete rumunske delegacije predvođene Nikolae Čaušeskuom Jugoslaviji od 27. maja do 1. juna.

${ }^{43}$ Lj. Dimić, Jugoslavija i Hladni rat, 327-329.

${ }^{44}$ AJ, KPR, I-3-a/97-21, Zajedničko saopštenje.
} 
tovanje tih principa spasiti Čehoslovačku od stranog upliva, samim tim Jugoslaviju i Rumuniju neizvesnog položaja. ${ }^{45}$

U periodu od drugog do trećeg susreta dvojice lidera, ali i neposredno posle toga došlo je do znatnog pogoršanja jugoslovenskog, a naročito rumunskog položaja. Tokom razgovora u Vršcu Tito i Čaušesku su bili primorani da govore o spremnosti da u slučaju ugrožavanja nezavisnosti zauzmu beskompromisan stav, što je uključivalo i oružani otpor. Sve jugoslovenske i rumunske analize su upućivale na to da je sovjetski napad neizbežan i da je samo pitanje vremena kada će se Moskva obračunati sa ,neposlušnim Bukureštom i Beogradom“. ${ }^{46}$ Nošeni trenutkom, Čaušesku i Tito su samo nekoliko sati nakon intervencije zvanično i veoma oštro osudili intervenciju pet zemalja Varšavskog pakta u Čehoslovačkoj. Scena Čaušeskuovog govora sa balkona ostala je upamćena kao herojska i često je upoređivana sa biblijskom pričom o Davidu i Golijatu. Tog 21. avgusta ,rumunski David je prkosio sovjetskom Golijatu“. ${ }^{47}$

Čaušesku je tokom razgovora u Vršcu isticao da je u odnosima sa SSSR-om došlo do zategnutosti, jer je Moskva bila „,besna“ zbog rumunske osude intervencije. ${ }^{48}$ Rumunija je smatrala da je sovjetsko rukovodstvo pošlo „,avanturističkim putem“, uopšte ne pazeći na interese socijalizma. Jugoslovenski vrh je sovjetski razlog intervencije, koji je nađen u opasnosti od Zapada, smatrao potpuno neosnovanim. Kao jedini razlog intervencije Beograd je video nemogućnost Moskve da prihvati samostalan put socijalističkih zemalja u socijalizam i da im dopusti samostalno rešavanje sopstvenih problema. ${ }^{49}$ Tito je intervenciju sagledavao kao deo mnogo šireg i dalekosežnijeg sovjetskog plana za učvršćivanje kontrole u okviru bloka. ${ }^{50}$

Ključno pitanje koje je posle okupacije ČSSR-a brinulo jugoslovensko rukovodstvo bilo je: „Da li se tu radi o učvršćivanju sovjetske sfere uticaja, pod čim se podrazumeva sređivanje sa ČSSR, pozivanje Rumunije na red, i neutralisanje i izolovanje Jugoslavije pritiscima, ili SSSR planira da stavi pod kontrolu i Rumuniju i Jugoslaviju, računajući na zauzetost SAD u Vijetnamu i pocepanost

\footnotetext{
${ }^{45}$ Shvatajući da se na primeru Čehoslovačke ispituju neki osnovni principi jugoslovenske spoljne politike CK SKJ nije mogao ostati po strani, morao je da oceni događaje i još jednom ponovi važnost principa nemešanja $u$ unutrašnje stvari druge zemlje. U znak podrške novom čehoslovačkom rukovodstvu Tito je posetio Prag. Ovom posetom od 9. i 10. avgusta, u vreme kada je definitivno doneta odluka o intervenciji, Jugoslavija se opredelila da po cenu sukoba sa SSSR-om, što je bilo neminovno, zadrži spoljnopolitičku orijentaciju i sačuva međunarodnu poziciju i ugled. (Д. Богетић, „Југословенско-совјетски односи у светлу војне интервенције у Чехословачкој 1968. године“, 129-162). Rumunija je poput Jugoslavije izražavala punu podršku čehoslovačkom rukovodstvu, a nekoliko dana posle Titove posete Pragu usledila je rumunska poseta. Prilikom Čaušeskuovog boravka u Pragu potpisan je ugovor između Čehoslovačke i Rumunije o prijateljstvu i uzajamnoj pomoći. „Ugovor savremenog tipa”, Politika, 16. 8. 1968, 3.

${ }^{46} \mathrm{AJ}, \mathrm{KPR}, \mathrm{I}-3-\mathrm{a} / 97-22$, Informacije o razgovorima Tito - Čaušesku.

${ }^{47}$ Vladimir Tismaneanu, Promises of 1968: Crisis, illusion and Utopia (Budapest: Central European University Press, 2011), 258.

${ }^{48}$ AJ, KPR, I-3-a/97-22, Zabeleške o razgovorima Tita i Čaušeskua, 24. avgust 1968.

${ }^{49} \mathrm{AJ}, \mathrm{KPR}, \mathrm{I}-3-\mathrm{a} / 97-22$, Informacije o razgovorima Tito - Čaušesku.

${ }^{50}$ AJ, KPR, I-3-a/97-22, Zabeleške o razgovorima Tita i Čaušeskua, 24. avgust 1968.
} 
Evrope?“. U jugoslovenskom vrhu se spekulisalo da bi naredna faza u politici SSSR-a mogla biti povećanje prisustva na Bliskom istoku i borba za pozicije na Balkanu i u istočnom Mediteranu, pa bi se u tom slučaju Jugoslavija našla na pravcu sovjetskog nastupanja. ${ }^{51}$

Jugoslovenske analize i procene sovjetske politike na osnovu dešavanja u Čehoslovačkoj smatrale su da sovjetski potezi u budućnosti mogu ići u dva pravca. Prvi, smirivanje situacije u svojoj interesnoj sferi, a drugi proširenje sovjetskog uticaja. Marko Nikezić je na zajedničkoj sednici Predsedništva i Izvršnog komiteta CK SKJ održanoj 2. septembra 1968. izneo dva stanovišta u pogledu kretanja sovjetske politike. Prvi, da SSSR samo želi da vrati poljuljan uticaj tako što će zgaziti Čehoslovačku, pozvati Rumuniju na red i neutralisati Jugoslaviju. Drugo stanovište je bilo da SSSR planira da iskoristi zauzetost SAD u Vijetnamu i proširi svoje pozicije ka Sredozemlju, Bliskom istoku i Balkanu. ${ }^{52}$

Jugoslovenskom rukovodstvu je iz izloženog bilo jasno da se Jugoslavija, i u jednom i u drugom slučaju, nalazila na putu sovjetskih planova. Njima je ostalo samo da vide kako će sovjetski planovi uticati na Jugoslaviju. Da li će se odnosi zadržati na kritikama i osudama ili će Moskva preduzeti konkretnije mere? Pokazaće se da su procene bile potpuno pogrešne - u stvarnosti SSSR je zauzimao znatno umereniji stav prema Jugoslaviji. U suštini sovjetska politika je posle 21. avgusta 1968. bila u defanzivi.

Razgovori u Vršcu su imali velikog uticaja na dalju rumunsku politiku. Unutar lagera položaj Rumunije ostao je vrlo delikatan i sa puno neizvesnosti, mada po rumunskom uverenju s vremenom je opasnost od vojne intervencije bila sve manja. Politika odbrane nezavisnosti Rumunije sve je više dolazila u direktnu konfrontaciju sa tendencijama intenzivnije vojne i ekonomske integracije lagera. Rumunija nije promenila svoj stav o intervenciji u Čehoslovačkoj. Smatrala je da se ovaj problem ne može rešiti sve dok se trupe ne povuku iz Čehoslovačke, ali zbog delovanja u pravcu smirivanja situacije to pitanje javno više nije iznosila. U rumunskoj štampi su bili primetni veća selekcija naslova, mirniji ton članaka i potenciranje pozitivnog toka razgovora u Moskvi. ${ }^{53}$

Jugoslovenski stavovi povodom okupacije ČSSR-a nailazili su na veliki odjek i širok publicitet u svim zapadnim kao i velikom broju azijskoafričkih zemalja, dok štampa zemalja koje su učestvovale u intervenciji nije obaveštavala o jugoslovenskim stavovima. Posebna pažnja na Zapadu pridavana je sastanku Tito-Čaušesku, što je gotovo od svih komentarisano u svetlu moguće opasnosti od sovjetske vojne intervencije. Francuska ga je okarakterisala kao simboličko stvaranje „male antante“ kojoj bi se jednog dana mogla priključiti i Dubčekova Čehoslovačka. Gotovo svi komentari podsećali su na 1948. godinu, ističući jugoslovenski politički kurs. Američka štampa je takođe

${ }^{51}$ DA MSP, PA, 1968, f. 74, dok. 433798, Stavovi DS o međunarodnoj situaciji, u vezi sa ČSSR krizom, izneti na sednici Spoljnopolitičkog odbora SNS 5. 9. 1968, 12. 9. 1968.

${ }^{52} \mathrm{Lj}$. Dimić, Jugoslavija i Hladni rat, 330-331.

${ }^{53}$ DA MSP, PA, Rumunija, 1969, f. 126, dok. 446487, Telegram, Uprava za Istočnu Evropu, 6. februar 1969. 
donosila stavove i aktivnosti Jugoslavije od prvog dana čehoslovačke krize. Njujork tajms je u uvodniku pod naslovom „Teško pogađanje u Moskvi“ dodatno proširio zebnje o sovjetskoj invaziji na Rumuniju i eventualno na Jugoslaviju. Od indirektnih napada sovjetska štampa je 24. avgusta prešla na direktne i grube napade na jugoslovenske stavove, gde se kaže da su se ,rukovodioci Rumunije i Jugoslavije pridružili imperijalističkom horu koji raspiruje političku histeriju u svojim zemljama i OUN““. 54

Razgovor u Vršcu je pokazao identičnost mišljenja i političku saglasnost, ali je imao relativno mali značaj za bezbednost Rumunije. ${ }^{55}$ Iznet je stav da i pored ozbiljnosti sukoba SSSR-a i Kine, Rumunija ne može da računa na realnu kinesku pomoć. Ocenili su da se moraju osloniti na svoje snage. Velika razlika u snazi nije pokolebala Rumune da u slučaju opasnosti pruže oružani otpor, ali kako bi se to izbeglo rumunsko rukovodstvo se na neko vreme odreklo ideje o napuštanju Varšavskog pakta. Sovjetski Savez je rumunsko rukovodstvo držao u neizvesnosti i prisiljavao ga da bude stalno na oprezu kako ne bi dao ni najmanji povod za intervenciju. Ta neizvesnost i strah odrazili su se na odnose Rumunije sa ostalim zemljama, pa i sa Jugoslavijom. Rumuniji je najviše odgovaralo da se osetljiva pitanja Varšavskog pakta i SEV-a i savetovanja odlože, da se normalizuju odnosi, da slučaj ČSSR ostane izolovan događaj, koji se ne bi mogao ponoviti. Kao što je Rumunija imala interes da Jugoslavija ne odustane od svojih principa, tako je i za Jugoslaviju bilo važno da Rumunija suviše ne popusti pod pritiskom SSSR-a. U opasnosti od sovjetskog hegemonizma viđen je i zajednički interes za saradnju i poboljšanje odnosa između dve susedne zemlje. ${ }^{56}$

Znatno umereniji stav Rumunije, prema tome, nije bio samo posledica razgovora u Vršcu već i velikog sovjetskog pritiska. Položaj Rumunije je bio veoma delikatan, jer je SSSR čvrsto rešio da ih na ovaj ili onaj način dovede $u$ položaj poslušnosti, što bi za rumunsko rukovodstvo i samog Čaušeskua značilo likvidaciju, jer su oni svu svoju politiku gradili oko nezavisnosti zemlje za koju su dobili i podršku partije i naroda. Rukovodstvo je bilo svesno činjenice da se Zapad pomirio s tim da je Rumunija u sovjetskoj interesnoj sferi i da neće pružiti pomoć u slučaju intervencije. Zato su se ubrzo posle 21. avgusta opredelili za

\footnotetext{
${ }^{54}$ DA MSP, PA, Rumunija, 1968, f. 74, dok. 431949, Reagovanje strane štampe na jugoslovenske stavove povodom okupacije ČSSR, 12.9. 1968.

${ }^{55}$ Za Nikolae Čaušeskua je bilo najvažnije da sazna na kakvu pomoć može Rumunija da računa od Jugoslavije i da li može da joj omogući otvoren koridor od Temišvara do Turn Severina. Ovaj koridor je za Rumuniju bio izuzetno važan, jer bi on u slučaju napada SSSR-a bio jedini pravac snabdevanja Rumunije oružjem i drugim ratnim materijalom. Zatvaranjem Crnog mora Rumunija bi se jedino mogla snabdevati preko Jugoslavije. Na pitanje snabdevanja preko Jugoslavije i jugoslovenske pomoći delegacija predvođena Titom nije imala odgovor. Smatrali su da o tome treba prvo dobro razmisliti. Jugoslavija nije želela da provocira i izaziva SSSR vojnim savezom sa Rumunijom, zbog čega je u tom trenutku jedino bila spremna da obeća kako neće dopustiti da Rumunija bude napadnuta sa jugoslovenske teritorije. AJ, KPR, I-3-a/97-22, Zabeleške o razgovorima Tita i Čaušeskua, 24. avgust 1968.

${ }^{56}$ DA MSP, PA, Rumunija, 1968, f. 156, dok. 437524, Telegram Bukurešt, broj 406, 18. 10. 1968.
} 
liniju davanja ustupaka i manifestacije prijateljstva sa zemljama Varšavskog ugovora, kao i izbegavanja osetljivih tema. ${ }^{57}$

Odnosi Rumunije i SSSR-a su počeli da se stabilizuju već od septembra 1968. Rumunsko izbegavanje teme o događajima u Čehoslovačkoj vodilo je smanjenju sovjetskog pritiska. Ovakav pravac u razvoju odnosa će kratko poremetiti uzbuna u novembru o navodnoj mogućnosti vojne intervencije u Rumuniji. Jugoslavija je ovu lažnu uzbunu razumela kao sovjetski pritisak radi disciplinovanja Rumunije. Smatrali su da će Rumunija zarad smirivanja situacije morati da napravi određene ustupke. Pritisak na Rumuniju je bio istovremeno i pritisak na Jugoslaviju. ${ }^{58}$

U tom smislu, važan događaj u odnosima Moskve i Beograda bilo je pismo Leonida Brežnjeva Josipu Brozu od 19. oktobra 1968. Brežnjev je u njemu izrazio želju i spremnost za smirivanje napetosti. Tito je odgovorio da Jugoslavija prihvata realno stanje u Čehoslovačkoj, ali da ostaje pri pređašnjim stavovima. Važnost ovih pisama je $u$ tome što su se lideri saglasili da je u interesu i jednih i drugih smanjivanje napetosti i zaustavljanje pogoršanja odnosa. Očito je da ni Jugoslavija ni SSSR nisu želeli da se vrati stanje iz 1948. godine i dođe do potpunog prekida odnosa. Ova kriza je samo uticala na političko zaoštravanje, dok je saradnja u ostalim oblastima nastavljena gotovo nesmetano. Treba istaći da i je, pored hladnih političkih odnosa, jugoslovensko-sovjetska trgovinska razmena bila na visokom nivou. ${ }^{59}$

\section{Zaključak}

„Praško proleće“ je bilo direktno inspirisano jugoslovenskim i rumunskim iskustvima koja su prethodila kontrolisanoj liberalizaciji. Približavanje Josipa Broza Tita i Nikolae Čaušeskua Aleksandru Dubčeku posle intervencije pet zemalja Varšavskog pakta izazvalo je strah u Jugoslaviji i Rumuniji da sledeći cilj sovjetskih tenkova ne budu oni. ${ }^{60}$ Rukovodstva obe zemlje su čak pomišljala da se zaustavi politika otvaranja i vrati na ortodoksnu marksističku liniju sovjetskog tipa; međutim, putevi Jugoslavije i Rumunije su suviše dugo bili razdvojeni od glavnog sovjetskog druma tako da vraćanje na staro nije bio moguće.

$\mathrm{U}$ vreme jedne od najvećih hladnoratovskih kriza u jugoslovenskorumunskim odnosima je dominirala samo jedna tema - odbrana od eventualnog napada. Rumunija je zbog blizine SSSR-a i članstva u Varšavskom paktu mnogo više strahovala od agresije nego Jugoslavija. Čehoslovačka kriza je za Josipa Broza Tita nastupila nakon formiranja već ustaljene spoljnopolitičke orijentaci-

57 DA MSP, PA, Rumunija, 1968, f. 156, dok. 438535, Mišljenje savetnika ambasade SRN Dručmana, 25. 10. 1968.

${ }^{58}$ Đ. Tripković, „Međunarodni položaj Jugoslavije i vojna intervencija u Čehoslovačkoj”, 127-130.

${ }^{59}$ DA MSP, PA, Jugoslavija, 1969, f. 81, dok. 422207, Materijal o odnosima Jugoslavije sa SSSR i ostalim zemljama Varšavskog ugovora, 16. 6. 1969.

${ }^{60}$ Francisko Veiga, „Sličnosti u političkom i društvenom životu Jugoslavije i Rumunije“, u: Balkan posle Drugog svetskog rata, ur. Petar Kačavenda i Dragan Bogetić (Beograd: Institut za savremenu istoriju, 1996), 245-253. 
je, usled čega je osuda intervencije za njega bila jedina moguća odluka. ${ }^{61}$ Doslednost u stavovima bila je za Jugoslaviju ključna za održavanje pozicije u svetu. To je bio još jedan veliki razlog koji je oblikovao jugoslovensko protivljenje i kritikovanje intervencije. Ne treba, međutim, zaboraviti da je Jugoslavija sa bliskoistočnom krizom postala bliska sa Sovjetskim Savezom i tada uspostavila posebno dobru vojnu saradnju. Jugoslavija je naročito kritikovala američki intervencionizam, militarizam i imperijalizam u Vijetnamu tokom 1968. godine, zbog čega je posebno bilo teško da se preko noći kritika preusmeri na SSSR. ${ }^{62}$ Tito, kao i Čaušesku uostalom, dobro je znao sovjetske prioritete i ciljeve. Svestan da se njegova država ne nalazi u interesnoj sferi Sovjetskog Saveza, ali sasvim blizu nje, on je mogao da pokaže nezadovoljstvo i iznosi kritike. Ipak preterano izazivanje Moskve svakako da nije bilo poželjno, a nije bilo ni u interesu Jugoslavije da ponovi 1948. godinu.

Rumunija je zbog svog položaja u okviru istočnog lagera i te kako bila svesna opasnosti koju nosi suprotstavljanje i kritikovanje političkih odluka Sovjetskog Saveza. Izolovana i gotovo sama predstavljala je laku metu za sovjetsku imperiju. Snovi koji su do tada postojali o američkoj pomoći su nestali tog 21. avgusta. Više nije bilo nedoumica oko podele između američke i sovjetske zone uticaja. ${ }^{63}$ Sama 1968. godina bila je izuzetno nepogodna za rumunsko vođenje nezavisne politike. Čaušesku je ubrzo posle prve burne reakcije uvideo da odnos velikih sila nije onakav kakav bi Rumuniji odgovarao. Rat u Vijetnamu je te godine za SAD bio od ključne važnosti, tako da Vašington nije imao dovoljno snage da se na pravi način posveti krizi u Čehoslovačkoj i pomogne jednoj lagerskoj zemlji da prkosi centru. ${ }^{64}$ Nikolae Čaušesku - delom razočaran Niksonovim slabim protestom protiv sovjetske intervencije, delom smirivan od strane Tita u Vršcu i svestan činjenice da ne može da računa na pomoć - odlučio je da zaštiti sebe i svoju državu i povede politiku smirivanja odnosa sa SSSR-om. Tog trenutka Rumunija je prestala da razmatra opciju izlaska iz Varšavskog pakta i da veruje u jaku podršku sa Zapada. Deceniju kasnije sve više ljudi je bilo uvereno da nema značajnih razlika između dve sfere uticaja. Utisak je bio da su Vašington i Moskva isti i da je i jedan i drugi centar u nekoj meri uskraćivao autonomiju svima koji su se nalazili ispod njih. $^{65}$

Odnosi Rumunije i Jugoslavije su duži niz godina bili u usponu. Razlog tome je svakako jugoslovenska podrška rumunskoj nezavisnoj politici. Sve do čehoslovačke krize se nije pojavio razlog za ograničavanje te saradnje. Tek je razgovorima $\mathrm{u}$ Vršcu Tito stavio do znanja rumunskom rukovodstvu da Jugoslavija nije spremna da uđe u vojni savez, što bi bez sumnje u Moskvi bilo

\footnotetext{
${ }^{61}$ Đ. Tripković, Jugoslavija - SSSR 1956-1971, 249-250.

${ }^{62}$ Vladimir Petrović, Titova lična diplomatija (Beograd: Institut za savremenu istoriju, 2010), 217.

${ }^{63}$ Џон В. Гедис, Хладни рат (Београд: Клио, 2003), 83.

${ }^{64}$ Od Arne Vestad, Globalni Hladni rat (Beograd: Arhipelag, 2008), 257.

65 John Lewis Gaddis, ,,On Moral Equivalency and Cold War History”, Ethnics and International Affairs, vol. 10, (1996), 131-148.
} 
shvaćeno kao direktno suprotstavljanje, na šta Tito nije bio spreman. Razgovori su bili prilika za definisanje granice buduće jugoslovensko-rumunske saradnje.

Nikolae Čaušesku je prihvatio savete Josipa Broza da, zbog osetljivog položaja i članstva u Varšavskom paktu, rumunsko rukovodstvo mora biti obazrivo i suzdržano u iznošenju stavova. Rumunska politika u narednom periodu je upravo išla linijom Titovih saveta. Rumunija je i pored isticanja svojih specifičnosti zadržala članstvo u Varšavskom paktu i pripadnost socijalističkoj zajednici sve do pada komunističkog sistema i Čaušeskuovog režima decembra 1989. godine.

Svet u kojem su Tito i Čaušesku već bili navikli da se snalaze i deluju i u kojem su imali kako-tako stabilnu i definisanu poziciju srušio se u noći 20/21. avgusta. Intervencija u Čehoslovačkoj uticala je da se dve države, zbog zajedničkog straha od potencijalne opasnosti od Sovjetskog Saveza, još više zbliže. Osim usaglašenih stavova oko intervencije u Čehoslovačkoj, Jugoslaviju i Rumuniju povezivala je i rešenost da svoju nezavisnost brane po svaku cenu. Beograd i Bukurešt su imali zajednički cilj - jačanje nezavisnosti i suprotstavljanje sovjetskim pritiscima. Posmatrano u celini 1968. godina je predstavljala vrhunac u jugoslovensko-rumunskim odnosima posleratnog perioda.

\section{REFERENCE}

- Bischof Günter, Stefan Karner, and Peter Ruggenthaler. The Prague Spring and the Warsaw Pact Invasion of Czechoslovakia in 1968. Plymouth: Lexington Books, 2010.

- Bogetić, Dragan. „Jugoslovensko-sovjetski odnosi u svetlu vojne intervencije u Čehoslovačkoj“. U: 1968 - četrdeset godina posle. Urednica Radmila Radić, 129-161. Beograd: Institut za noviju istoriju, 2008.

- Bogetić, Dragan. Jugoslovensko-američki odnosi 1961-1971. Beograd: Institut za savremenu istoriju, 2012.

- Bondžić, Dragomir. Između ambicija i iluzija. Nuklearna politika Jugoslavije 1945-1990. Beograd: Institut za savremenu istoriju, 2016.

- Crowder, B. Ashby. Legacies of 1968: Autonomy and Represion in Ceausescu's Romania 1965-1989. Ohaio, 2007.

- Dimić, Ljubodrag. „Godina 1968 - ishodište nove jugoslovenske politike“. U: 1968 - četrdeset godina posle. Urednica Radmila Radić, 339-375. Beograd: Institut za noviju istoriju, 2008.

- Dimić, Ljubodrag. Jugoslavija i Hladni rat. Beograd: Arhipelag, 2014.

- Dragomir, Elena. „The perceived threat of hegemonismin Romania during the second de'tente“. Cold War History, vol. 12, no. 1, (February 2012), 111-134.

- Gaddis, John Lewis. „On Moral Equivalency and Cold War History”. Ethnics and International Affairs, vol. 10. (1996), 131-148.

- Gedis, L. Džon. Hladni rat. Beograd: Clio, 2003.

- Judt, Tony. Postwar: A History of Europe since 1945. New York: Penguin Press, 2005. 
- Klasić, Hrvoje. Jugoslavija i svijet 1968. Zagreb: Ljevak, 2012.

- Laker, Volter. Istorija Evrope 1945-1992. Beograd: Clio, 1999.

- McDermott Kevin, and Matthew Stibbe. Eastern Europe in 1968: Responses to the Prague Spring and Warsaw Pact Invasion. Cham: Palgrave MacMillan, 2018.

- Petrović, Vladimir. Titova lična diplomatija. Beograd: Institut za savremenu istoriju, 2010.

- Retegan, Mihai. In the Shadow of the Prague Spring: Romanian Foreign Policy and the Crisis in Czechoslovakia, 1968. Buchurest: Center for Romanian Studies, 2000.

- Schmid, Sonja. „Nuclear Colonization?: Soviet Technopolitics in the Second World“. In: Entangled Geographies: Empire and Techologies in the Global Cold War. Editor Gabrielle Hecht, 125-155. Cambridge: MIT Press, 2011.

- Tismaneanu, Vladimir. Promises of 1968: Crisis, illusion and Utopia. Budapest: Central European University Press, 2011.

- Tripković, Đoko. „Međunarodni položaj Jugoslavije i vojna intervencija u Čehoslovačkoj“. Istorija 20. veka, god. XXVI, br. 1, (2008), 115-130.

- Tripković, Đoko. Jugoslavija - SSSR 1956-1971. Beograd: Institut za savremenu istoriju, 2012.

- Veiga, Francisko. „Sličnosti u političkom i društvenom životu Jugoslavije i Rumunije“. U: Balkan posle Drugog svetskog rata. Urednici Petar Kačavenda i Dragan Bogetić, 245-253. Beograd: Institut za savremenu istoriju, 1996.

- Vestad, Od Arne. Globalni Hladni rat. Beograd: Arhipelag, 2008. 
MA NEMANJA MITROVIĆ, Research Grantee

Institute for Contemporary History

Belgrade, Republic of Serbia

nmitrovic3@gmail.com

\section{INTERNATIONAL PROBLEMS VIEWED THROUGH TALKS BETWEEN NICOLAE CEAUȘESCU AND JOSIP BROZ TITO IN 1968}

\section{Summary}

The importance of a scholarly study of Yugoslav-Romanian relations during 1968 comes from the fact that this cooperation had outgrown its bilateral context. Tighter contact between two countries was reflected in frequent and cordial visits of the highest-ranking officials. Among those contacts, the most important were meetings of the two heads of state, Nicolae Ceaușescu and Josip Broz Tito. In 1968 alone they met three times. The first meeting was in early 1968, the second was during the Romanian delegation's official visit from May 27 to June 1, and the third one happened just days after the Soviet intervention in Czechoslovakia.

Mutual interests such as opposition to superpower hegemony, the defense of sovereignty and peaceful coexistence, independent foreign policy, and cooperation on equal terms, were especially stressed during the talks between Josip Broz Tito and Nicolae Ceaușescu. Hence these three visits were of special importance for understanding the relations between Yugoslavia and Romania in 1968. The main topics of the talks during the visits were: mutual consulting of the communist parties, relations with the USSR, international crises such as the one is the Middle East, but some crucial subjects also emerged during that eventful year, i.e. the non-proliferation deal and the events in Czechoslovakia.

As one of the greatest emergencies of the Cold War, the Czechoslovakia crisis triggered a defense from potential foreign invasion and dominated Yugoslav-Romanian relations. The relations between Romania and Yugoslavia were on the rise for a number of years. That influenced Belgrade to support more independent policy of Bucharest. However, the crisis in Czechoslovakia also put a limit to this cooperation. During the talks in Vršac Tito clearly said that Yugoslavia is not ready for a military alliance which would provoke the Soviet Union. The talks in Vršac were the opportunity to define the limits of Yugoslav-Romanian cooperation.

KEYWORDS: Yugoslavia, Romania, Josip Broz Tito, Nicolae Ceausescu, Prague Spring, 1968, Cold War 